\title{
Financial Integration, Domestic Investment and Growth of Pakistan Economy
}

\author{
* Gulzar Ali (Corresponding Author) \\ ** Awoesha Rahat \\ *** Said Zamin Shah
}

\begin{abstract}
This study, in the context of Pakistan, analyzes to which extent the financial integration and domestic investment are responsible for the phenomenal growth rate of Pakistan economy. The relationship is based on time series data covering a period from 1980 to 2018. In analytical techniques, the Augmented Dicky-Fuller unit root test for the stationarity of data, Johansen Co-integration for cointegrating factor, and Vector Error Correction Model (VECM) for phenomenal relation between domestic investment, financial integration and growth of Pakistan economy were applied. The results obtained through regression analysis were statistically significant and showed the effective role of the causality of domestic investment and that of financial integration on the economic growth rate of Pakistan economy. The effect of political and economic stability captured through the dummy variable also shows an impressive role in the growth of Pakistan's economy. The study recommends that sturdy efforts are required of the government of Pakistan for target investment especially in the agriculture and manufacturing sector for a more fruitful outcome.
\end{abstract}

Keywords: Financial Integration, Domestic Investment, Political and Economic Stability, Economy of Pakistan

\section{Introduction}

The economic integration, domestic investment, and economic growth go side by side, in countries that are predominantly less developed and developing. Domestic investment has potentially increased the wellbeing of people in multiple ways. In the first place, there has been greater access to visible improvements in various sectors of economies as well as of economic activities that create greater opportunities for employment and income-generating activities. In the second place, its benefits producers with abundant outputs; finally, the availability of more quantity reduces the costs thereby ultimately increasing the income level of the net buyers (IFPRI 2011). However, the effect of financial integration on the growth of economies has mostly been considered dually. Firstly, on one side, the financial integration brings improvement in financial markets that is in the form of money capital as well as brings up-gradation in the real or physical capital that increases the productive efficiency and accumulation of capital leads to an affirmative effect on economic growth. While on the other hand, due to an increase in capital and productive efficiency the saving rate increases that lead to an increase in investment, thus leading to an encouraging effect on growth (Schularick \& Thomas, 2007).

Domestic investment helps in determining the level and fluctuation in national income as well as overall economic activity in a country. The decline in investment spending during a recession usually drops down the expenditure on goods and services, which in turn lowers down the return to capital against the higher profit during the boom (Blinder, 2008). Looking into the broader perspectives, the developed countries in general and the developing world desire an economy where chances for investment prevails and increases over time. Thus, the significance of domestic investment cannot be undermined as it plays a dual role; on one side (short-run) it affects output through aggregate demand while on the other side (long-run), it creates capital formation on potential output via aggregate supply (Herzer, 2011).

\footnotetext{
* Department of Economics, Islamia College University Peshawar, Khyber Pakhtunkhwa, Pakistan Email: gulzaricup@yahoo.com

** Department of Management Sciences, Women University Mardan, Khyber Pakhtunkhwa, Pakistan

*** Department of Economics, Islamia College University Peshawar, Khyber Pakhtunkhwa, Pakistan
} 
Domestic investment in various sectors of the economy is crucial to capture capital stock; the formation of capital stock and sustain economic growth. It contributes to the economic growth and development of the country considerably. Ignoring domestic investment temporarily can lead to issues of food security and widespread poverty vis-à-vis employment reduction. It can also slow down the production processes of the downstream industries as such industries due to a shortage of raw materials. The overall contribution to economic growth and prosperity of the country would become grim and dark.

Many of the researchers have of the view that financial integration brings a rapid increase in economic activities and thus boost economic growth (Pagano, 1993, Prasad et al., 2004; Aziakpono, 2013). Moreover, there exists a strong connection between capital market, monetary development, and financial integration. The capital market reconciliation positively affected the productive efficiency and growth of economies, and emphatically influenced the financial capital (Obstfeld \& Taylor, 2004). Financial integration across the globe conveys comparative advantage and thus leads to an increase in production, exports, international trade, saving, and investments leads to a positive effect on the growth of economies. Thus, financial integration may channel advantages for profitable activities, and portfolio investment allowing the economy to improve (Kim et al., 2004). It is also worth examining the importance of financial integration at the international level too and to realize the profound effect on international and national financial and real capital market (Quinn, 2003; Quinn \& Toyoda, 2008). In general, with international market integration, the competition especially for developing countries production increases that sometimes leads to adverse effects on productive efficiency, productivity, and growth of developing economies (Reisen \& Soto, 2001).

\section{Research Objective}

This study highlights the importance and role of domestic investment and financial integration in the growth of Pakistan's economy. The included factors of the study may have far-reaching ramifications and may help policymakers in suggestions for stable growth and plummeting of investment opportunities. Consequences of the decline in the domestic investment may harm most of the economic activities that are the mainstay of income and employment generation as well as raising the webbings of the individuals.

\section{Literature Review}

Coming to the contribution of investment, worth noticing is the promotion of technology which raises the productive capacity of the economy and increases employment level. Many exiting literatures has found a positive association between technology adoption, capital formation, and growth of economies (Agenor, 2003; Prasad et al., 2003; Wooldridge, 2007). Some studies in the Indian context, however, have made a distinction with aspects of private and public sector investment with the latter being more advantageous and contributing towards the growth of economies (Mougani, 2010). According to (Nosirjon, 2013) due to more liberalization of financial integration, its effect on growth has more comprehensive. Moreover, the study found an impressive effect of financial integration on the growth of the stock market as well as on trade openness and increasing employment opportunities. Galindo et al., (2002) investigated the different link through which financial integration affect investment and leads to a satisfactory effect on economic growth. According to the study, financial integration permits foreign investors and financial institutions to operate in various countries leads to improvement in the financial institution in the country. Thus through the successful maneuver of the foreign institution strengthen the internal financial system, cause the interest rate to become low, and thus by providing more credit to the investors, the investment activity in the country increase leads to its more significant effect on the growth of the economy.

The financial integration, especially of the banking sector, leads to encouraging effect on the investment by lowering and liberalization of interest rate and uniform government policy management thus leads to a substantial effect on growth (Henry, 2000; Bekaert \& Harvey, 2000; Levine, 2001; Eyraud et al., 2017). However, the enormous alleged pressures on the domestic monetary system lead to an uncontrolled and volatile effect on growth especially in emerging and developing countries (Anderson, et al., 2005). Joseph (2010) recommends that developing nations, even though related to high factor profitability, were in an ideal situation with financial autarky. As indicated by (Ahmed, 2011; Mougani, 2012; Kouki \& Rezgui, 2017), the significance of domestic investment in the growth of economies haul financial development comes from the way that it produces positive overflows in the economy and helps in improvement in technology and infrastructure, productivity and wellbeing. 
Different examination studies studied the relationship between public investment and its effect on the growth of economies that mostly leads to a positive and favorable effect (Graham \& Otto, 2003). Ghani and Din, (2006) found that public investment has a positive effect on the growth of the Pakistan economy.

Khan (1996) investigated the effect of investment in enhancing the economic growth of developing countries. The findings expressed that the effect of private investment on the growth of developing countries is higher as compared to that of public investment. Various observational studies have embraced the vector auto-regressive methodology (VAR) way to deal with analyzes the connection between financial integration, investment, government speculation, and monetary development (i.e. Kim et al., 2004; Jin, 2006; Ghani \& Din, 2006). The favorable VAR models successfully explored and explained the role of financial integration and investment in the growth of economies (Ghani \& Din, 2006). Applying VAR methodology, Sturm (1998) found that investment has an imperative effect on output growth in Netherland, whereas, (Mittnik \& Neumann, 2001) concluded that investment has a positive effect on growth as well as the study didn't found any crowding out effect between private and public investment. Financial integration is the procedure that affects the growth of economies through improvement in financial process, economic, political, and technological improvements (Hussen, 2020). Moreover, due to the emergence of globalization, the role of international financial integration becomes more effective and leads to a satisfactory role in enhancing economic growth. The advantage of globalization appears to lead to monetary integration that has a positive effect on the growth and development of the country (Claessens et al, 2010; Lane, 2012; Didier et al., 2012; Hussen, 2020).

The importance of financial integration and investment got much attention especially after the world economic and financial crises that happen at the $1^{\text {st }}$ decade of this century, and the relationship of financial integration and growth to be one of the most discussed issues among the financial analysts Methodological Framework and Analysis

The financial integration affects the growth of economies in different ways. It has a direct and indirect effect on growth. According to neo-classical, financial integration affects the growth of the economy by stimulating domestic investment and saving (Kose et al., 2006; Henry, 2006). This is referred to as the direct method of the effect of financial integration on the growth of the economy. Through indirect, the financial integration stimulates the growth of the economy by strengthening and developing the macro-economic policy, economic stability, improvement in policies in governance etc. however, this study for the measurement of indirect effect used a dummy variable to capture the effect of political and economic stability and its relation with the growth of Pakistan economy vial financial integration, regressed the following model for examining the direct and indirect effect of financial integration.

$\mathrm{GDP}=\alpha_{0}+\alpha_{1} \mathrm{FI}_{\mathrm{t}}+\alpha_{2} \mathrm{DI}_{\mathrm{t}}+\alpha_{3} \mathrm{D}+\mu_{\mathrm{t}}$

The unit root test is applied for the stationarity of data variables. Firstly, all the variables are tested at level applying both the ADF and PP tests. However, all the variables show non-stationarity at level on both tests as given in table (1). After examining the variables at level and of non-stationarity outcomes, the ADF and PP tests are applied at $1^{\text {st }}$ difference where all the variables show the stationarity on both tests as given in table (1).

Table: 1. Unit Root Tests Results

\begin{tabular}{llllll}
\hline Variables & Acronyms & \multicolumn{2}{l}{ ADF Test Outcomes } & \multicolumn{2}{l}{ PP Test Outcomes } \\
& & I $(\mathbf{0})$ & I $(\mathbf{1})$ & $\mathbf{I}(\mathbf{0})$ & I (1) \\
\hline Economic Growth & GDP & $\mathbf{- 1 . 1 8 0 8 5}$ & $\mathbf{- 4 . 1 9 9 4 3 1}$ & $\mathbf{- 1 . 3 7 8 5 0 2}$ & $\mathbf{- 5 . 1 7 3 5 6 8}$ \\
Financial Integration & FI & $\mathbf{- 1 . 2 9 7 5 2}$ & $\mathbf{- 4 . 5 7 4 8 3}$ & $\mathbf{- 1 . 5 3 4 8 1 3}$ & $\mathbf{- 6 . 4 6 4 4 7 4}$ \\
Domestic Investment & DI & $\mathbf{- 1 . 2 5 2 1 5 3}$ & $\mathbf{- 5 . 0 3 9 5 8 0}$ & $\mathbf{- 1 . 3 6 9 9 6 2}$ & $\mathbf{- 6 . 1 2 0 3 4 0 7}$ \\
Dummy Variable & D & $-\mathbf{- 1 . 1 6 3 3 1 0}$ & $\mathbf{- 4 . 3 5 3 2 9 9}$ & $\mathbf{- 1 . 2 8 1 7 4 3}$ & $\mathbf{- 5 . 7 5 1 8 6 5}$ \\
\hline
\end{tabular}

(*) shows rejection of the null hypothesis of unit root at 5\%

After testing the variables for stationarity and obtaining the level of stationarity at $1^{\text {st }}$ difference by all variables, the Johansen co-integration test is applied to examine the order of integration and the co-integration vector among the variables. The study found that there are two cointegrating factors among the variables as both the trace statistics and Eigenvalues are greater than critical values for the first two vectors. Moreover, the finding reveals that there is a long-run relationship between financial integration, domestic investment, and growth of the Pakistan economy 
Table: 2. Johansen Co-integration Results

\begin{tabular}{|c|c|c|c|c|c|c|c|c|c|}
\hline \multicolumn{2}{|c|}{ Hypothesis } & \multirow[t]{2}{*}{ Trace Stat. } & \multirow{2}{*}{$\begin{array}{l}\text { Critical } \\
\text { Value }\end{array}$} & \multirow[t]{2}{*}{ Prob. } & \multicolumn{2}{|c|}{ Hypothesis } & \multirow{2}{*}{ Max Eigen } & \multirow{2}{*}{$\begin{array}{l}\text { Critical } \\
\text { Value }\end{array}$} & \multirow[t]{2}{*}{ Prob. } \\
\hline $\mathrm{H}_{0}$ & $\mathbf{H}_{1}$ & & & & $\mathbf{H}_{0}$ & $\mathbf{H}_{1}$ & & & \\
\hline $\mathbf{Z}=\mathbf{0}$ & $\mathrm{Z} \geq \mathbf{0}$ & 80.78296 & 47.85613 & 0.0000 & $\mathrm{Z}=\mathbf{0}$ & $\mathrm{Z} \geq \mathbf{0}$ & 46.29923 & 27.58434 & 0.0001 \\
\hline$Z \leq 1$ & $Z \geq 1$ & 34.48373 & 29.79707 & 0.0134 & $Z \leq 1$ & $\mathrm{Z} \geq 1$ & 28.96733 & & 0.0032 \\
\hline$Z \leq 2$ & $Z \geq 2$ & & & & $\mathbf{Z} \leq$ & $Z \geq$ & 089 & & 782 \\
\hline $\mathrm{Z} \leq \mathbf{3}$ & $\mathrm{Z} \geq \mathbf{3}$ & 0.019307 & 3.841466 & 0.8894 & $\mathrm{Z} \leq \mathbf{3}$ & $\mathrm{Z} \geq \mathbf{3}$ & 0.019307 & 3.841466 & 0.8894 \\
\hline
\end{tabular}

This study examining that either financial integration, domestic investment as well as political and economic stability has an effective role in the growth of Pakistan economy. For that purpose, the different techniques have been applied to investigate the co-integration between financial integration, domestic investment, and growth, the Johansen co-integration test is applied. The text clarifies the comprehensible outcome that between financial integration, domestic investment, and growth of Pakistan economy, there is a co-integration and showed that these factors (domestic investment \& financial integration) have long run connection with the economy of Pakistan.

Now to further, examine the effect and co-integration of the co-efficient of financial integration, domestic investment, and growth of Pakistan economy, the vector error correction model is regressed. The result of the ECM co-integrating equation in table (3) gives up as a noteworthy effect for financial integration on growth. Thus, the finding shows that financial integration leads to considerable effect on growth.

Table: 3. ECM Co-integrating co-efficient Results

\begin{tabular}{lllcc}
\hline Variables & D $($ GDP $)$ & D(FI) & D(DI) & D(D) \\
\hline Co-efficient & $\mathbf{1 . 0 0 0 0 0 0}$ & -1.170621 & -1.492063 & -1.974925 \\
Std. error & --- & $(0.12904)$ & $(0.18195)$ & $(0.24058)$ \\
t-stat. & --- & {$[-9.07209]$} & {$[-8.20042]$} & {$[-8.20888]$} \\
\hline
\end{tabular}

In this era of financial globalization, receptiveness to the worldwide capital market positively affected the development pace of an economy through its effect on aggregate investment. However, it is not necessary that inaugural up to the international capital market deliberately leads to an increase in domestic investment, capital accumulation, and saving rate. However, the nations that are profoundly open to the global market, succeeded in attracting foreign capital, and accompanied by domestic investment have gained rapid growth in their economies. The results in table (3) estimated that financial integration accompanies by domestic investment has an effective role and strongly cointegrated both variables with the growth of the Pakistan economy. Moreover, the increase in investment leads to an increase in the inflow of capital, and thus the development impacts of financial integration on both financial and real capital is substantially increased.

The impact of financial integration on the growth of economies as well as on financial development has customarily included tremendous enthusiasm from numerous investigators. It is also a fact that the role and importance of financial integration and its coordination in capital improvement either that are in terms of monetary improvement or terms of real capital development have gotten more eloquent during the worldwide crises, particularly for nations experiencing significant change in their growth and development. The countries that have comparative benefits in trade and especially in exports are more likely to do the effective financial integration that leads to the momentous effect of production via capital accumulation and investment that also affirms their impressive role in the growth of the economies.

Table: 4. Error Correction Model Analysis Results

\begin{tabular}{llccl}
\hline Error Correction: & D(LOG(GDP)) & D(LOG(FI)) & D(LOG(DI)) & D(LOG(D)) \\
\hline CointEq1 & -0.043045 & -0.427887 & -0.490881 & -0.033799 \\
& $(0.02053)$ & $(0.08112)$ & $(0.17992)$ & $(0.01589)$ \\
D (LOG (GDP (-1))) & {$[-2.09695]$} & {$[-5.27447]$} & {$[-2.72826]$} & {$[-2.12692]$} \\
& -0.700781 & -0.021135 & -0.052377 & -1.866324 \\
& $(0.28276)$ & $(0.00972)$ & $(0.01324)$ & $(1.85948)$ \\
D (LOG (FI (-1))) & {$[-2.47839]$} & {$[-2.17391]$} & {$[-3.95725]$} & {$[-1.00368]$} \\
& -0.105423 & -0.887294 & -0.735608 & -0.014652 \\
& $(0.03046)$ & $(0.22945)$ & $(0.26700)$ & $(0.02358)$ \\
D (LOG (DI (-1))) & {$[-3.46083]$} & {$[-3.86703]$} & {$[-2.75512]$} & {$[-0.62135]$} \\
& 0.080113 & 0.662083 & 0.998276 & 0.036958 \\
& $(0.03328)$ & $(0.25065)$ & $(0.29166)$ & $(0.02576)$
\end{tabular}




\begin{tabular}{lcccc}
\hline & & & & \\
$\mathbf{D}(\mathbf{L O G}(\mathbf{D}(-\mathbf{1})))$ & {$[2.40756]$} & {$[2.64150]$} & {$[3.42273]$} & {$[1.43472]$} \\
& -0.031575 & -0.817858 & -0.494184 & -0.044313 \\
& $(0.11792)$ & $(0.88819)$ & $(1.03353)$ & $(0.09128)$ \\
$\mathbf{C}$ & {$[-0.26778]$} & {$[-0.92081]$} & {$[-0.47815]$} & {$[-0.48545]$} \\
& 0.134897 & 0.274100 & 0.351678 & 0.067329 \\
& $(0.02865)$ & $(0.21580)$ & $0.25111)$ & $(0.02218)$ \\
R-squared & {$[4.70848]$} & {$[1.27014]$} & {$[1.40047]$} & {$[3.03581]$} \\
Adj. R-squared & 0.857588 & 0.798736 & 0.762514 & 0.751495 \\
\hline
\end{tabular}

The relationship between financial integration, domestic investment, and growth of the economy -the extent of the effect of financial integration and investment on growth especially through financial and real capital is the most discussing and debating issue nowadays especially among the financial and economic experts. Moreover, the investigator is also interested to know that which economies through financial integration and investment, achieve faster's growth that either financially more open economies become faster than closed ones, precisely considering their openness to financial capital markets? The economy of Pakistan is considered an open economy and this study investigated the impact of financial integration and domestic investment on the growth of Pakistan economy.

The finding of the study shows the considerable effect of financial integration on the growth of the Pakistan economy. Further, the coordination and effect of financial integration improves the growth performance of the economy, which indicates that the effect would be dependent upon explicit kinds of capital inflows. The receptiveness financial integration corresponding to growth was test-ably e examine on the economy of Pakistan by regressing the ECM. The result of the ECM co-efficient estimator in table (4) shows that receptivity of financial integration is significant is at $1 \%$ and indicates a noteworthy causal effect. The finding of this study supports the disclosures of the financial experts who believe in the goals of overall capital adaptability.

One basic motivation behind of domestic investment is to also boost and invest that sector of the economy too in which the private sector did not invest or in which they feel uncertain. The fundamental inspiration of such activity is to drive the growth of various sectors that leads to a momentous effect on growth. The findings of domestic investment given in table (4), show that domestic investment has a satisfactory effect and causality with financial integration that leads to a satisfactory effect on the growth of the Pakistan economy.

On the political environments, a strong democratic rule and stability are necessary and convincing conditions or the fundamental merits to attract the business community for investment. However, policies and regulations when governed and pushed by one man in power rather than the nation's aspirations always hold back the investors from taking investment initiatives. Since, 2008, Pakistan is experiencing a positive change in the form of having democratic rule one after another. But the government has had to step in aggressively to realize a more mature and safe environments for increasing competition among the investors. An investor is primarily interested in maximizing profits and minimizing risk. In the absence of political stability, the investor cannot predict the future and he would remain quite uncertain of the outcomes of his investment adventure.

\section{Conclusion}

The study has identified the significant factors of the growth of the Pakistan economy, like financial integration and domestic investment which can be used as policy variables to get the desired results for growth. The results reveal that financial integration turned out to be a significant determinant of investment activity which in turn can be decisive in analyzing the behavior and growth of Pakistan economy. While estimating financial integration and domestic investment functions the level of political stability and favorable economic condition of a country and their possible effects on government policies are also captured through the dummy variable. The result indicates these qualitative factors (political stability and economic environment) are equally significant determinants of growth.

The study recommends that to enhance investment opportunities further, the concerned authorities are required to create additional demand for Pakistani products by exploring the world market through various export promotion measures. Also, the government should ensure one desk facilitation in major cities for equal facilitation of domestic and overseas investors. 


\section{Limitation of the Study}

The main limitation of this study is that its scope is very narrow, in the future may be the study needs to be conducted on taking sample study of many countries i.e. developing, SAARC, Asian countries, European countries, etc.

Further, due to time and data constrain, the variables of the study are limited. In the future, by taking some more moderate variables of financial integration, the study will be more effective.

\section{References}

Agenor, D. (2003), Benefits and Costs of International Financial Integration: Theory and Facts, World Economy, 26, 34-47.

Ahmed, A. D. (2011). International Financial Integration, Investment, and Economic Performance in Sub-Saharan African Countries. Global Economy Journal, 11(4), 165-179.

Aziakpono, M. (2013). Financial integration and economic growth: Theory and a survey of evidence. Journal for Studies in Economics and Econometrics, 37(3), 1-18

Bekaert, G., \& Harvey, C. (2000). Foreign Speculators and Emerging Equity Markets. Journal of Finance, 55, 565-613.

Blinder, A. S. (2008). Keynesian economics. The concise encyclopedia of economics, 2, 1-12.

Claessens, S., Laeven, L., Igan, D., \& Dell'Ariccia, G. (2010). Lessons and Policy Implications from the Global Financial Crisis. IMF Working Papers, 44(10), 1-37.

Didier, T., Hevia, C., \& Schmukler, S. (2012). How resilient and Counter-cyclical were Emerging Economies during the Global Financial Crisis? Journal of International Money and Finance, 31(8), 2052-2077

Eyraud, L., Singh, D., \& Sutton, B. (2017). Benefits of Global and Regional Financial Integration in Latin America. IMF Working Papers, 1(17), 1-32.

Galindo, A. J., Fabio, S., \& Andrew, M. W. (2002). Does Financial Liberalization Improve the Allocation of Investment? Micro Evidence from Developing Countries. SSRN Electronic Journal, 3(2), 37-49.

Ghani, E., \& Din, M.-U., (2006). The impact of public investment on economic growth in Pakistan. The Pakistan Development Review, 45(1), 87-98.

Graham, M. V., \& Otto, G. (2003). Public Investment and Economic Growth. Applied Economics, 130

Henry, B. P. (2006). Capital account liberalization: Theory, evidence, and speculation. NBER Working Paper 12698.

Henry, P. (2000). Stock Market Liberalization, Economic Reform, and Emerging Market Equity Prices. The Journal of Finance, 55(2), 529-564.

Herzer, D. (2011). Does Foreign Aid Increase Investment? Evidence from Panel Co-integration. Applied Economics, 11(2), 165-178.

Hussen, A. A. (2020). Impact of Financial Integration on Ethiopian Economic Growth. Business and Economic Research, 10(1), 55-76.

Jin, C. (2006). Can openness be an engine of sustained high growth rates and inflation? Evidence from Japan and Korea. International Review of Economics and Finance, 15, 228-240.

Khan, M. S. (1996) Government Investment and Economic Growth in the Developing World. The Pakistan Development Review 35, 419-439.

Kim, S., Kim, S. H. \& Wang, Y. (2004). Macroeconomic effects of capital account liberalization: The case of Korea. Review of Development Economics, 8(4), 624-639.

Kose, M. A., Prasad, E., Rogoff, K., and Wei, S. (2006). Financial globalization: A reappraisal. NBER Working Paper 12484.

Kouki, S., \& Rezgui, S. (2017). The impact of financial integration on economic growth. Case of Maghreb countries. Archives of Business Research, 5(3), 70-79.

Lane, P. (2012). Financial Globalization and the Crisis. BIS Working Papers, 397, 1-42.

Levine, R. (2001). International Financial Liberalization and Economic Growth. Review of International Economics, 9(4), 688-702.

Mittnik, S., \& T. Neumann, (2001) Dynamic Effects of Public Investment: Vector Autoregressive Evidence from Six Industrialized Countries. Empirical Economics, 26, 429-446. 
Mougani, F. (2012). An Analysis of the Impact of Financial Integration on Economic Activity and Macroeconomic Volatility in Africa within the Financial Globalization Context. African Development Bank Group, Working Paper No.144.

Nosirjon, J. (2013). Financial Integration and Economic Growth. MPRA Paper No. 55711

Obstfeld, M. \& Taylor, A. M. (2004). Global capital markets: Integration, crises, growth. Cambridge: Cambridge University Press.

Pagano, M. (1993). Financial markets and growth: An overview. European Economic Review, 37, 613-622.

Prasad, A., Rogoff, K., Wei, S., \& Kose, M. A. (2004). Financial globalization, growth, and volatility in developing countries. NBER Working Paper Series No. 10942.

Prasad, E., Rogoff, K., Wei, S., \& Kose, A. (2004) Effects of Financial Globalization on Developing Countries: Some Empirical Evidence. Economic and political weekly 38(41)

Quinn, D. (2003). Capital account liberalization and financial globalization, 1890-1999: A synoptic view. International Journal of Finance and Economics, 8(3), 189-204.

Quinn, D. P., \& Toyoda, M. (2008). Does capital account liberalization lead to growth? Review of Financial Studies, 21(3), 1403-1449.

Reisen, H., \& Soto, M. (2001). Which types of capital inflows foster developing country growth? Journal of International Finance, 4(1), 1-14.

Schularick, M., \& Thomas, M. Steger. (2007). Financial Integration, Investment, and Economic Growth; Evidence from Two Eras of Financial Globalization. CESifo Working Paper No. 1691.

Solomon, T. (2010). Perspectives on financial integration and financial architecture in emerging markets.

Wooldridge, D. P., Domanski, D., \& Cobau, A. (2003) Changing links between mature and emerging financial markets. BIS Quarterly Review, September. 